\title{
Validation of the self-assessment of communication skills and professionalism for nurses
}

\author{
Validação do self-assessment of communication skills and professionalism para enfermeiros
}

Certificación de la autoevaluación de las habilidades de comunicación y profesionalismo para enfermeros

\begin{tabular}{|c|c|}
\hline $\begin{array}{l}\text { Thaís Josgrilberg Perei } \\
\text { 'Universidade Guarulhos, Postgraduat }\end{array}$ & $\begin{array}{l}\text { Ana Claudia Puggina' } \\
\text { ogram in Nursing. São Paulo, Brazil. }\end{array}$ \\
\hline $\begin{array}{l}\text { How to cit } \\
\text { Pereira TJ, Puggina AC. Validation of the self-assessmer } \\
\text { Rev Bras Enferm [Internet]. 2017;70(3):588-94. D }\end{array}$ & $\begin{array}{l}\text { article: } \\
\text { ommunication skills and professionalism for nurses. } \\
\text { tp://dx.doi.org/10.1590/0034-7167-2016-0133 }\end{array}$ \\
\hline Submission: 04-25-2016 & Approval: 12-11-2016 \\
\hline $\begin{array}{l}\text { Objetivos: traduzir, adaptar culturalmente e validar para o p } \\
\text { and professionalism in residents para o profissional enfermeir } \\
\text { interferem na autoavaliação sobre o profissionalismo e comur } \\
\text { Resultados: A amostra foi de } 110 \text { enfermeiros com média de } \\
\text { A consistência interna da escala "Autoavaliação sobre pro } \\
\text { paciente" apresentou confiabilidade moderada e satisfatória (o } \\
\text { Interpessoal, Troca de Informação, Sinceridade na Relação e } \\
\text { na língua portuguesa e para a cultura brasileira. A habilidad } \\
\text { informações foi influenciada pelo sexo e setor de atuação. A a } \\
\text { Descritores: Relação Paciente-Enfermeiro; Comunicação; Con }\end{array}$ & $\begin{array}{l}\text { uês o instrumento Self-assessment of communication skills } \\
\text { aliar se características pessoais e de atuação do enfermeiro } \\
\text { âo interpessoal. Método: estudo metodológico quantitativo. } \\
\text { e de } 32 \text { anos }( \pm 7,3) \text { e a maioria mulheres ( } n=80 ; 72,7 \% \text { ). } \\
\text { nalismo e comunicação interpessoal entre enfermeiro e } \\
\text { 12). A análise fatorial identificou quatro fatores: Habilidade } \\
\text { sionalismo. Conclusão: o instrumento é válido e confiável } \\
\text { rpessoal modificou-se com sexo e estado civil. A troca de } \\
\text { aliação do profissionalismo modificou-se com estado civil. } \\
\text { ação Não-Verbal; Autoavaliação; Estudos de Validação. }\end{array}$ \\
\hline
\end{tabular}

\section{ABSTRACT}

Objectives: to translate, adapt cross-culturally and validate into Brazilian Portuguese the following instrument: "Self-assessment of communication skills and professionalism in residents" for the nursing professional, and to determine if personal characteristics and performance of the nurse interfere in the self-assessment about professionalism and interpersonal communication. Method: quantitative study. Results: the sample consisted of 110 nurses with mean age of 32 years old $( \pm 7.3)$, most of them were women $(\mathrm{n}=80 ; 72.7 \%)$. The internal consistency of the scale "Autoavaliação sobre profissionalismo e comunicação interpessoal entre enfermeiro e paciente" presented moderate and satisfactory reliability $(\alpha=0,712)$. Factorial analysis identified four factors: Interpersonal Skills, Exchange of Information, Honesty in the Relationship and Professionalism. Conclusion: the instrument is valid and reliable in Portuguese and for Brazilian culture. Interpersonal Skills changed with gender and marital status. Ability to exchange information was influenced by gender and working sector. Self-assessment of professionalism changed with marital status.

Descriptors: Nurse-patient Relationship; Communication; Nonverbal Communication; Self-assessment; Validity Studies.

\section{RESUMEN}

Objetivos: traducir, adaptar culturalmente y certificar para la lengua portuguesa el instrumento de Autoevaluación de las Habilidades de Comunicación y Profesionalismo de residentes para el enfermero profesional y evaluar si las características personales y de actuación del enfermero interfieren en la autoevaluación del profesionalismo y de la comunicación interpersonal. Método: trata-se de un estudio metodológico cuantitativo. Resultados: La muestra estaba formada por 110 enfermeros con edad promedio de 32 años $( \pm 7,3)$ y la mayoría eran mujeres $(n=80 ; 72,7 \%)$. La consistencia interna da la escala "Autoevaluación sobre profesionalismo y comunicación interpersonal entre enfermero y paciente" demostró confiabilidad moderada y satisfactoria $(\alpha=0,712)$. El análisis factorial identificó cuatro factores: Habilidad Interpersonal, Intercambio de Información, Sinceridad en las Relaciones y Profesionalismo. Conclusión: el instrumento es válido y confiable en la lengua portuguesa y para la cultura brasileña. La habilidad interpersonal osciló en relación con el sexo y el estado civil. El intercambio de informaciones fue influenciado por el sexo y el sector de actuación. La autoevaluación del profesionalismo sufrió variaciones según el estado civil. Descriptores: Relación Paciente-Enfermero; Comunicación; Comunicación No Verbal; Autoevaluación; Estudios de Validación. 


\section{INTRODUCTION}

Communication is a form of interaction in which individuals share opinions, ideas, information, messages and feelings, and it may influence people's behavior, causing reactions related to beliefs, culture, reality and life history of those involved ${ }^{(1)}$.

Interpersonal relationship between professionals and patients uses communication as a basic element, in order to allow the patients to understand their problems and treatment plan $^{(1)}$. The professional that demonstrates communication skills may handle the situations of dealing with patients more effectively. Communication is an essential skill in the professional training of healthcare professionals ${ }^{(2)}$.

Instruments that assess communication can be of great value for individual interventions, improving relationships and care. However, evaluating interpersonal communication more thoroughly may demand more than one technique or the use of different instruments, such as observation of interactions, group dynamics, recording and interpreting non-verbal communication, among others ${ }^{(3)}$.

Considering the importance of communication in the doctor-patient relationship, the American Board of Internal Medicine (ABIM) uses an instrument in which the patient evaluates the physician, part of an analysis of continuing professional development of the medical professional, to address communication skills.

Based on the instrument used by ABIM, the "Self-assessment of communication skills and professionalism in residents" is a scale composed of 11 items, measured by a 3-point Likert scale, divided into two subscales: Interpersonal Relations and Conveying Medical Information. The validity study of this questionnaire indicated an internal consistency reliability of 0.82 for the Interpersonal Relations subscale and of 0.80 for the Conveying Medical Information subscale ${ }^{(4)}$.

The objectives of this study were to translate, adapt cross-culturally and validate into Portuguese the instrument "Self-assessment of communication skills and professionalism in residents", the first modified version of the ABIM instrument, elaborated by Symons, Swanson, McGuigan, Orrange e AkI $(2009)^{(4)}$. It was initially proposed for medical residents and nursing professionals, in order to evaluate if personal characteristics and performance of the professional interfere in the self-assessment about professionalism and interpersonal communication.

\section{METHOD}

\section{Ethical aspects}

Authorization from the researcher Andrew Symons was requested to translate, adapt and validate the instrument. The development of the study met the national and international standards of research ethics involving human beings, based on Resolution 466/12.

\section{Design, study location and period}

This is a quantitative study carried out in two phases: content validation, which includes translation and cross-cultural adaptation, and construct validation.
The study was conducted in five hospitals and two higher education institutions in the city of Dourados, in the State of Mato Grosso do Sul. Data collection occurred from February to September 2014.

\section{Sample size; inclusion and exclusion criteria}

The convenience sample consisted of 11 Nursing professors for the pre-test phase. For the pre-final phase, the calculation of the minimum value for validation of the instrument was obtained through the recommended criterion of 10 participants per item of the original scale, adding up to 110 participants ${ }^{(5)}$.

As inclusion criterion, the participants should be nursing assistants or Nursing professors who guide internships within hospital units. Nurses on vacation, maternity leave, medical leave or that only acted in administrative functions were excluded.

\section{Study protocol}

The internationally recommended steps for the process of cross-cultural adaptation and validation were followed in order to evaluate linguistic and cultural equivalence between the original and translated versions: translation, synthesis, back translation, expert committee review, pretesting, and pre-final testing ${ }^{(5)}$.

In the first stage, translations T1 and T2 were performed by two independent bilingual translators, one who knew the theme of the scale and one who did not. In a second stage, a third bilingual professional, with knowledge of the Brazilian culture and language and of the English language proposed a synthesis of the two translations (T12).

After the synthesis of the translations, in a third step, two Native American translators developed the back translation (R1 and R2), only accessing the synthesis of the translations.

In the fourth stage, a committee of judges with 10 professionals was appointed, having among them: bilinguals; methodologists; health professionals; linguists and translators. In possession of the T1, T2, T12, R1 and R2 versions and the scale application guidelines, the committee compared the versions, evaluating the semantic and idiomatic equivalence, and then a pre-test version proposal was elaborated (Figure 1).

Semantic equivalence is understood as the evaluation of correspondence of grammar and vocabulary between the versions, since there are words from one language that do not have an adequate translation for another. Idiomatic equivalence addresses the difficulties in translating colloquial expressions of a given language ${ }^{(6)}$.

In the fifth and last step of the content validation process, 11 teaching nurses evaluated the pre-test version qualitatively, answering the scale items and then answering two essay questions in order to verify if there was any doubt or difficulty understanding the items.

From the suggestions obtained in the pre-test, the pre-final version of the scale "Autoavaliação sobre profissionalismo e comunicação interpessoal entre enfermeiros e pacientes" was elaborated and then submitted to evaluation of the psychometric properties.

In the content validity study of the original instrument, the 11 items were initially measured by a five-point Likert scale, but with the statistical tests, the American authors ${ }^{4}$ chose to 
group the answers in a three-point Likert scale for a better presentation of the results. In the current study, the five-point Likert scale was maintained.

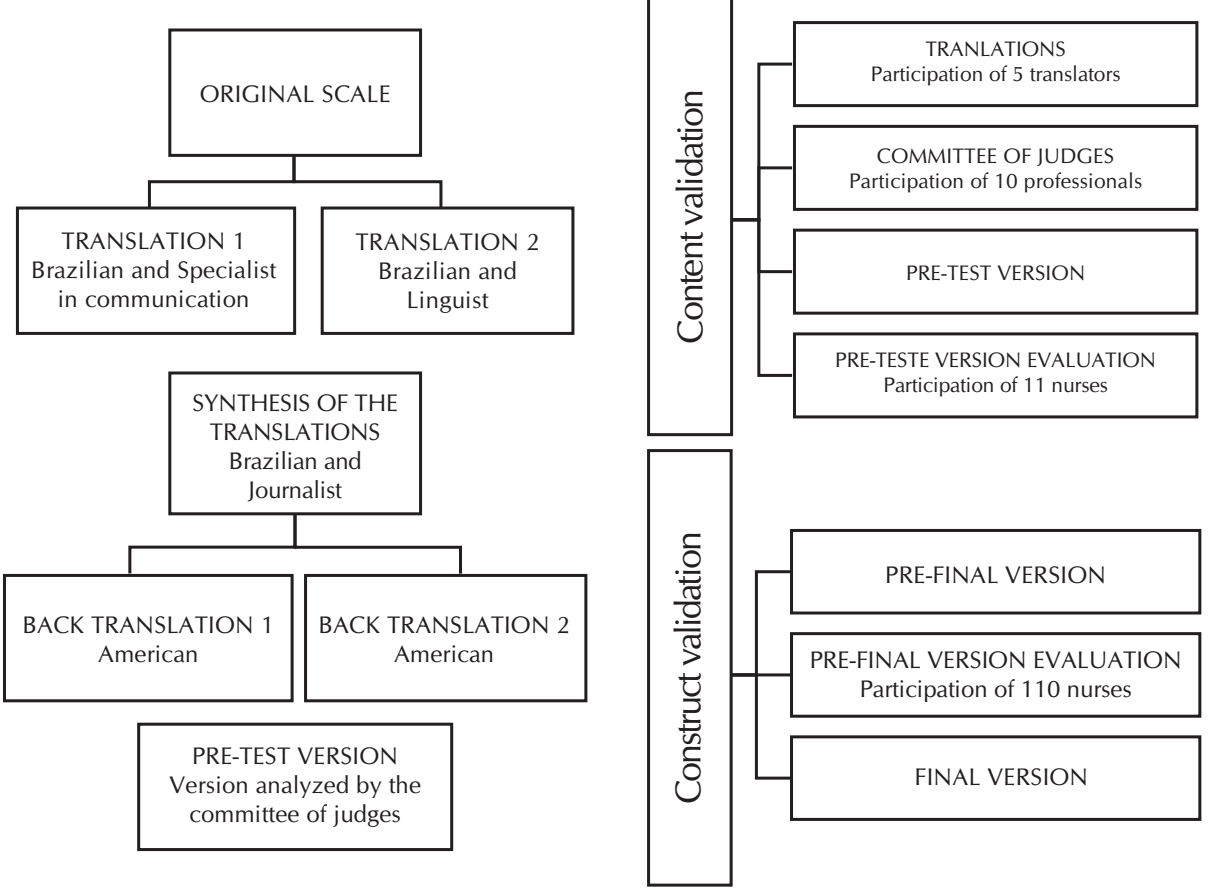

Figure 1 - Steps of the validation process, characteristics of the translators and number of participants in each stage, Dourados, Mato Grosso do Sul, Brazil, 2014

$(\mathrm{n}=50 ; 45.5 \%)$. Regarding professional training time, the mean was 6 years $( \pm 4,8)$, and most of the participants were specialists $(n=69 ; 62.7 \%)$. The most frequent working sector was the medical ward $(n=48$; $43.6 \%$ ) followed by intensive care units $(\mathrm{n}=29 ; 26.4 \%)$.

In this study, the coefficient of internal consistency of the scale "Autoavaliação sobre profissionalismo e comunicação interpessoal entre enfermeiros e pacientes" presented moderate reliability of 0.712 . Moderate reliability is when the Cronbach's Alpha is between 0.65 and 0.75 , however, an alpha over 0.70 is considered satisfactory ${ }^{(4)}$.

The factorial analysis identified four factors: Interpersonal Skills (items 2, 3, 4 and 5), Exchange of Information (items 6, 7 and 8), Honesty in the Relationship (items 1 and 9) and Professionalism (Items 10 and 11). (Table 1)

The Cronbach's alpha was calculated for each item. The lowest result was in item 5 , with a value of 0.662 , and the highest results were in items 1 and 10, which obtained the same Alpha of

A three-point Likert scale is less reliable and cannot accurately demonstrate the interviewee opinion; a five-point scale, is generally more accurate, easier and faster than a seven-point scale ${ }^{(7)}$.

\section{Result analysis and statistics}

Construct validation was conducted through statistical analysis of the data from the pre-final test, using factorial analysis. The reliability of the instrument was verified through Cronbach's Alpha. The factors were established through factorial analysis, having as criterion of number of domains the value $>1$, and as criterion for the input of variables in the domain the 0.5 flag.

The factors of the scale "Autoavaliação sobre profissionalismo e comunicação interpessoal entre enfermeiros e pacientes" were studied regarding the distribution of data through the Kolmogorov-Smirnov test. Since they did not show adherence to the normal distribution curve, they were studied according to the characteristics of the sample using Mann-Whitney nonparametric tests (when the variable addressed was divided in two categories) or Kruskal-Wallis (when the variable addressed was divided in 3 or more categories). The significance level was set at $5 \%$. The software used for analysis was SAS version 9.5.

\section{RESULTS}

The sample consisted of 110 nurses, with a mean age of 32 years $( \pm 7.3)$, mostly women $(n=80 ; 72.7 \%)$ and mostly single
0.715, showing that all items are within a moderate and satisfactory Cronbach's alpha. Correlations between items and total were positive, indicating consistency between items and total. (Table 2)

Table 1 - Factors obtained through Rotation of Factors, Dourados, Mato Grosso do Sul, Brazil, 2014

\begin{tabular}{ccccc}
\hline & $\begin{array}{c}\text { Factor } \mathbf{1} \\
\text { Interpersonal } \\
\text { Skills } \\
\mathbf{n}\end{array}$ & $\begin{array}{c}\text { Factor } \mathbf{2} \\
\text { Exchange of } \\
\text { Information }\end{array}$ & $\begin{array}{c}\text { Factor } \mathbf{3} \\
\text { Honesty in the } \\
\text { Relationship }\end{array}$ & $\begin{array}{c}\text { Factor } \mathbf{4} \\
\text { Professionalism }\end{array}$ \\
\hline 1 & 3 & 5 & $82^{*}$ & $\mathbf{n}$ \\
2 & $70^{*}$ & -14 & -1 & 7 \\
3 & $86^{*}$ & -3 & 8 & -20 \\
4 & $54^{*}$ & 34 & 18 & 21 \\
5 & $89 *$ & -1 & 9 & -17 \\
6 & 6 & $79 *$ & -19 & 17 \\
7 & -11 & $61 *$ & 36 & 1 \\
8 & -2 & $76^{*}$ & 32 & 1 \\
9 & 23 & 19 & $71 *$ & -2 \\
10 & 6 & 2 & 11 & -8 \\
11 & 12 & 2 & 13 & $-70^{*}$ \\
\hline
\end{tabular}

Note: *Values are multiplied by 100 and rounded; Higher values are grouped into factors. 
Table 2 - Cronbach's alpha and correlation with the total by item of the scale "Autoavaliação sobre profissionalismo e comunicação interpessoal entre enfermeiro e paciente”, Dourados, Mato Grosso do Sul, Brazil, 2014

\begin{tabular}{|c|c|c|c|}
\hline & & $\begin{array}{l}\text { Correlation } \\
\text { with total }\end{array}$ & $\begin{array}{l}\text { Cronbach's } \\
\text { alpha }\end{array}$ \\
\hline & Items & $\mathbf{n}$ & $\mathbf{n}$ \\
\hline 1 & Telling them everything; being truthful, upfront and frank; not keeping things from them that they should know. & 0.202 & 0.715 \\
\hline 2 & Greeting them warmly; calling them by the name they prefer; being friendly, never crabby or rude. & 0.406 & 0.685 \\
\hline 3 & Treating them like they're on the same level; never "talking down" to them or treating them like a child. & 0.459 & 0.676 \\
\hline 4 & $\begin{array}{l}\text { Letting them tell their story; listening carefully; asking thoughtful questions; not interrupting them while } \\
\text { they're talking. }\end{array}$ & 0.447 & 0.678 \\
\hline 5 & Showing interest in them as a person; not acting bored or ignoring what they have to say. & 0.552 & 0.662 \\
\hline 6 & Warning them during the physical exam about what you are going to do and why; telling them what you find. & 0.230 & 0.711 \\
\hline 7 & $\begin{array}{l}\text { Discussing options with them; asking their opinion; offering choices and letting them help decide what to } \\
\text { do; asking what they think before telling them what to do. }\end{array}$ & 0.302 & 0.700 \\
\hline 8 & Encouraging them to ask questions; answering them clearly; never avoiding their questions or lecturing them. & 0.477 & 0.673 \\
\hline 9 & Explaining what they need to know about their problems, how and why they occurred, and what to expect next. & 0.395 & 0.686 \\
\hline 10 & $\begin{array}{l}\text { Using words they can understand when explaining their problems and treatment; explaining any technical } \\
\text { medical terms in plain language. }\end{array}$ & 0.205 & 0.715 \\
\hline \multirow[t]{6}{*}{11} & How would you rate your level of professionalism? & 0.274 & 0.705 \\
\hline & Factors & & \\
\hline & Interpersonal Skills & 0.376 & 0.402 \\
\hline & Exchange of Information & 0.336 & 0.439 \\
\hline & Honesty in the Relationship & 0.314 & 0.458 \\
\hline & Professionalism & 0.241 & 0.519 \\
\hline
\end{tabular}

Internal consistency of the instrument was assessed through Cronbach's Alpha. The results were conclusive to confirm homogeneity in the items and there was a positive correlation between them, meaning that when one increases the other also tends to increase, indicating consistency between the factors and the total. Regarding the factors identified and the alpha value, the alpha was relatively low. However, they presented positive correlation, therefore they should not be used as subscale and there was no suggestion to eliminate an item. (Table 2)

The scale "Autoavaliação sobre profissionalismo e comunicação interpessoal entre enfermeiros e paciente" has 11 items, measured through a five-point Likert scale in items 1 to 10 (1- never, 2- rarely, 3- sometimes, 4- often, 5- always) and another Likert scale in item 11 (1- low, 2- low to moderate, 3- moderate, 4- moderate to high, 5- high). Higher scores indicate a better self-assessment on professionalism and nurse-patient communication. The mean total score of the participants' answers was $47.8( \pm 3.99)$. (Table 3$)$.

Regarding the descriptive analysis of the participant's answers in the scale "Autoavaliação sobre profissionalismo e comunicação interpessoal entre enfermeiro e paciente" there was a majority of "always" answers in the items $2(\mathrm{n}=71$; $64.5 \%), 3(n=89 ; 80.9 \%), 5(n=76 ; 69.1 \%), 6(n=63 ; 57.3 \%)$ e $10(n=84 ; 76.4 \%)$. These answers show that the nurses interviewed greet patients, call them by their names, are friendly, treat them as equals, show interest in them as people, warn them during the physical exam about what they are going to do and why, use understandable words and explain the technical terms used. There was also a majority of the answer "moderate to high" in the item $11(\mathrm{n}=68 ; 61.8 \%)$, in which nurses classify their level of professionalism. 
Comparing the characteristics of the sample with the factors of the scale, a statistically significant difference was found in the factor Interpersonal Skills associated with Gen$\operatorname{der}(p$-value $=0.047)$. This result shows that women self-report themselves as having better Interpersonal Skills. Another statistically significant association, still related to Gender ( $p$-value $=0.037$ ) was identified in the factor Exchange of Information, in which women also presented better selfassessment. (Table 4)

Table 4 - $\quad$ Analysis of the scale factors "Autoavaliação sobre profissionalismo e comunicação interpessoal entre enfermeiro e paciente" according to characteristics of the sample, Dourados, Mato Grosso do Sul, Brazil, 2014

\begin{tabular}{lcccc}
\hline & Mean & $\begin{array}{c}\text { Standard } \\
\text { deviation }\end{array}$ & Median & $\begin{array}{c}\boldsymbol{p} \\
\text { value }\end{array}$ \\
\hline & \multicolumn{4}{c}{ Interpersonal Skills } \\
\hline n & $\mathbf{n}$ & $\mathbf{n}$ & $\mathbf{n}$ \\
\hline Gender* & & & & 0.047 \\
Female & 18.4 & 2.2 & 19.0 & \\
Male & 17.9 & 1.6 & 18.0 & \\
Marital status & & & & 0.020 \\
Single & 17.8 & 1.6 & 18.0 & \\
Married & 18.5 & 2.5 & 19.0 & \\
Widowed & 19.0 & - & 19.0 & \\
Separated & 18.0 & 0.0 & 18.0 & \\
Divorced & 19.0 & 0.8 & 19.0 & \\
Cohabiting & 18.8 & 1.0 & 19.0 & \\
\hline
\end{tabular}

\begin{tabular}{lllll}
\hline \multicolumn{4}{c}{ Information Exchange } & \\
\hline $\begin{array}{l}\text { Gender* } \\
\text { Female }\end{array}$ & 12.7 & 1.8 & 13.0 & 0.037 \\
$\quad$ Male & 11.7 & 2.1 & 12.0 & \\
Working sector & & & & 0.036 \\
ICU & 12.6 & 1.6 & 13.0 & \\
Surgery Center & 12.3 & 1.6 & 12.0 & \\
Emergency room & 12.3 & 1.5 & 12.0 & \\
Ward & 12.7 & 1.9 & 13.0 & \\
Ambulatory & 11.0 & 3.2 & 12.0 & \\
Other & 9.3 & 1.7 & 9.5 & \\
\hline
\end{tabular}

\section{Professionalism}

Marital status 0.036

$\begin{array}{lccc}\text { Single } & 8.7 & 0.8 & 9.0 \\ \text { Married } & 9.1 & 0.7 & 9.0 \\ \text { Widowed } & 8.0 & - & 8.0 \\ \text { Separated } & 8.5 & 0.7 & 8.5 \\ \text { Divorced } & 8.8 & 1.9 & 9.5 \\ \text { Cohabiting } & 9.3 & 0.8 & 9.5\end{array}$

Note: Kruskal-Wallis Test / *Mann-Whitney Test; ${ }^{1}$ Others: Hospital Infection Commission and Bandaging Commission; ICU - Intensive Care Unit.
Statistical relevance was found in the characteristic Marital Status in relation to the factor Interpersonal Skills ( $p$-value $=$ 0.020), in which single professionals presented a lower performance when compared to married, widowed, separated, divorced or cohabiting professionals. (Table 4)

Association between the variable Working sector and the factor Information Exchange ( $p$-value $=0.036$ ) showed statistical significance. The sector identified as "others", which includes the Hospital Infection Commission and the Bandaging Commission, had a mean of 9.3 and stood out as the sector that least performs exchange of information. (Table 4)

The variable Marital Status related to the factor Professionalism ( $p$-value $=0,036)$ presented statistical relevance. Married and cohabiting individuals assessed themselves with better professionalism and more adequate use of language with the patient (Table 4).

\section{DISCUSSION}

The choice for an instrument created in another culture and another language gives the researchers, and the others involved, a challenge to make it suitable for a new reality, which is faced through a systematic method of translation and cross-cultural adaptation. Cross-cultural adaptation involves a process that analyzes language through translation and studies issues related to the cultural adaptation, within the stages to adapt an instrument to a new reality. As this is a prerequisite for studies carried out using the same instrument in different cultures ${ }^{(8)}$.

This study is the first to test the psychometric properties through the validity and reliability tests of this instrument for the Brazilian reality. Research instruments that allow comparisons between different realities broaden the discussion about the subject of interest.

The communication process is complex and involves intrinsic and extrinsic factors. Interpersonal relationships occur through verbal and non-verbal messages, and the non-verbal dimension is more expressive than the verbal one ${ }^{(1)}$, since people do not say all they think or feel. However, verbal communication tends to be less subjective than manifestations involving gesture, facial and body expressions and tone of voice.

The fact that the proposed instrument is a self-assessment instrument, which depends on the reflexive and critical capacities of the professionals concerning their own performance, can be a limitation of the instrument. However, because it is predominantly based on the self-assessment of verbal communication, the individual can answer the items more easily. This instrument may be useful for quick diagnoses as well as for the education and improvement of nurse-patient interpersonal communication.

The first factor, Interpersonal Skills, addresses the ability of the individual to react to the presence of the other and emphasizes non-verbal communication, including the gestures used, the treatment dispensed to the other person, listening, demonstrating interest for the other. If this ability is evaluated with a high value, it means that the individual self-assesses herself/himself as capable of effectively interacting.

In this study, competence and ability are regarded as synonyms, as in another study ${ }^{(3)}$. Interpersonal ability or interpersonal competence is the ability to deal effectively with 
interpersonal relationships, interacting with others according to the particular situations and to the needs of the other ${ }^{(9)}$.

The factor Exchange of Information shows the professional's ability to send and receive relevant information. If the professionals' self-assessment in the three items included in this factor is high, it shows that, according to their opinion, they send and receive clear, objective and adequate information and maintain a coherent communication process.

This factor is based on verbal communication, which must be bidirectional and have the messages validated in order to be considered effective ${ }^{(1)}$. An adequate and effective communication contributes to the quality of the nurses' care, especially in unknown procedures, which bring fear and anxiety to the patient.

The third factor is Honesty in the Relationship. The items in this factor demonstrate the need to tell the patient everything that is pertinent during health monitoring. The nurse that selfassessed himself/herself with high values in the items 1 and 9 confirmed they were honest in this relationship, indicating the veracity of the information, given with no distortion.

A qualitative study addressing comprehensive care, with a diverse population including teachers, students, health services managers and nurses concluded, based on their speeches, that the care must be based on a committed, responsible, sincere and trustworthy relationship between users and professionals ${ }^{(10)}$. Honesty, as it can be observed, is also regarded in other realities, such as comprehensive care, emphasizing professional relationships.

The last factor, Professionalism, is composed by two items in which the nurses evaluate their professionalism according to their own perspective. Professionalism involves intense and continuous acquisition of knowledge, standards and behaviors that are essential to a proper exercise of the professional activity $^{(11)}$. In the context of the scale, the factor Professionalism is understood as directly related to communication skills.

Considering the associations made in the present study, interpersonal skills and ability to exchange information depend on gender. Other studies ${ }^{(12-13)}$ found in the literature also indicate a possible association between interpersonal communication and gender.

A European study explored gender differences in emerging language skills in 13,783 European children from 10 non-English language communities. For this, the authors used an adapted version of the MacArthur-Bates Communicative Development Inventories. The results showed that girls are slightly ahead of boys in early communicative gestures, in productive vocabulary, and in combining words. The difference increased with age. Despite the large variation in language skills between communities, the difference between girls and boys remained. This suggests that the difference is caused by intrinsic factors that do not change between communities ${ }^{(12)}$.

Another study concluded that the ability to perceive and understand others' intentions and actions depends on gender. For this, the authors administered a visual task to female and male participants of two groups, adolescents between 13 and 16 years old and young adults. The main outcome of the study showed no difference in the performance of the task by female and male participants in both groups; however, the findings were discussed in terms of gender-related behavioral components and brain mechanisms involved in visual social perception $^{(13)}$.

The association between a higher self-assessment of professional/interpersonal communication and marital status might be explained by the experience and the challenges experienced in cohabiting. One study evaluated the salience and severity of relationship problems in 862 newlywed spouses ( $n=431$ couples) who had to list their three biggest sources of disagreement and rate the severity of problems described in a standard inventory of relationship problems. Comparing the two sources of information, it was found that, although relational problems (e.g., communication and moods) were classified as severe in the inventory, challenges external to the relationship (e.g. children) were more salient in the free listing task ${ }^{(14)}$. Couples face important challenges, not only for relational problems, but also related to stress caused by external factors, and this experience might bring maturity and strengthening of interpersonal skills.

The results found in this study regarding the influence of the working sector on the exchange of information between nurse and patient can be related to the characteristics of the units studied: ICU and ward versus Hospital Infection Commission and Bandaging Commission. The statistical relevance found might be due to the fact that the professionals who work in these commissions have a less frequent contact with patients and a very objective and straight-forward performance.

\section{Limitations of the study}

As a limitation of the study, we can point out the varying size of the institutions in which data were collected. This may be related to the participants' answers, considering that in a smaller institution the understanding of the communication skills may be clearer than for nurses working in larger institutions. Another limitation is the fact that the proposed instrument is a self-assessment instrument, meaning it relies on reflexive and critical capacities of professionals on their own performance, so it only assesses the professional's self-perception.

\section{Contributions to the area of nursing}

The validated instrument is a contribution to the nursing area, since it is an instrument for easy measurement of communication skills between nurse and patient. It may be able to bring improvement in this issue and it highlights communication as necessary for the professional training and performance of the nursing professional.

\section{CONCLUSION}

The scale "Autoavaliação sobre profissionalismo e comunicação interpessoal entre enfermeiro e paciente" presents good reliability and good internal consistency. Therefore, it is a reliable instrument for the nursing professional to self-evaluate themselves regarding professionalism and interpersonal communication.

Interpersonal skills of the individuals was different depending on gender and marital status. The nurse's ability to exchange information with the patient was influenced by gender and working sector. Self-assessment of professionalism also depended on marital status. 


\section{REFERENCES}

1. Silva MJP. Comunicação tem remédio: a comunicação nas relações interpessoais em saúde. $10^{\circ}$ ed. São Paulo: Loyola, 2015.

2. Munari DB, Bezerra ALQ. Inclusão da competência interpessoal na formação do enfermeiro como gestor. Rev Bras Enferm [Internet]. 2004 [cited 2015 Jan 19];57(4):484-6. Available from: http://www.scielo.br/pdf/reben/v57n4/v57n4a20.pdf

3. Puggina AC, Silva MJ. Interpersonal Communication Competence Scale: Brazilian translation, validation and cultural adaptation. Acta Paul Enferm. 2014 [cited 2015 Mar 25];27(2):108-14. Available from: http://www.scielo.br/pdf/ape/v27n2/en_0103-2100-ape-27-02-0108.pdf

4. Symons AB, Swanson A, McGuigan D, Orrange S, Akl EA. A tool for self-assessment of communication skills and professionalism in residents. BMC Med Educ [Internet]. 2009 [cited 2015 Jun 02];9(1):1-7. Available from: https://www.ncbi.nlm.nih.gov/pmc/ articles/PMC2631014/pdf/1472-6920-9-1.pdf

5. Beaton DE, Bombardier C, Guillemin F, Ferraz MB. Guidelines for the process of cross-cultural adaptation of self-report measures. Spine. 2000;25(24):3186-91.

6. Ciconelli RM, Ferraz MB, Santos W, Meinão I, Quaresma MR. Tradução para a língua portuguesa e validação do questionário genérico de avaliação de qualidade de vida SF-36 (Brasil SF-36). Rev Bras Reumatol [Internet]. 1999 [cited 2016 Mar 31];39(3):143-50. Available from: http://www.uff.br/renato_nunes/files/2014/03/Valida\%C3\%A7\%C3\%A3o-do-Question\%C3\%A1 rio-de-qualidade-de-Vida-SF-36.pdf

7. Dalmoro M, Vieira KM. Dilemas na Construção de Escalas Tipo Likert: o número de Itens e a disposição influenciam nos resultados? RGO [Internet]. 2013 [cited 2015 Apr 12];6(3):161-74. Available from: http://bell.unochapeco.edu.br/revistas/index php/rgo/article/view/1386/1184

8. Avansi PA, Meneghin P. Translation and adaptation of the In-hospital Utstein Style into the Portuguese language. Rev Esc Enferm USP [Internet]. 2008 [cited 2015 Mar 25];42(3):504-11. Available from: http://www.scielo.br/pdf/reeusp/v42n3/en_v42n3a12.pdf

9. Moscovici F. Desenvolvimento interpessoal: treinamento em grupo. $21^{\circ} \mathrm{ed}$. Rio de Janeiro: José Olympio, 2012.

10. Leonello VM, Oliveira MAC. Integralidade do cuidado à saúde como competência educativa do enfermeiro competência educativa do enfermeiro. Rev Bras Enferm [Internet]. 2010 [cited 2015 Jan 19];63(3):366-70. Available from: http://www.scielo. br/pdf/reben/v63n3/a03v63n3.pdf

11. Martins e Silva J. Mundo do Trabalho no Contexto da Formação Médica. Educação médica e profissionalismo. Rev Acta Med Port [Internet]. 2013 [cited 2015 mar 2];26(4):420-7. Available from: http://www.actamedicaportuguesa.com/revista/index.php/amp/ article/view/1284/3716

12. Eriksson M, Marschik PB, Tulviste T, Almgren M, Pérez Pereira M, Wehberg S, et al. Differences between girls and boys in emerging language skills: evidence from 10 language communities. Br J Dev Psychol [Internet]. 2012[cited 2015 Jun 02];30(Pt2):326-43 Available from: https://www.ncbi.nlm.nih.gov/pubmed/22550951

13. Pavlova M. Perception and understanding of intentions and actions: does gender matter? Neurosci Lett. 2009;449(2):133-6.

14. Jackson GL, Trail TE, Kennedy DP, Williamson HC, Bradbury TN, Karney BR. The salience and severity of relationship problems among low-income couples. J Fam Psychol [Internet]. 2016 [cited 2016 Dec 02];30(1):2-11. Available from: https://www.ncbi. nlm.nih.gov/pmc/articles/PMC4742400/pdf/nihms730408.pdf 